\title{
The Democratizing Effects of Transnational Actors' Access to International Courts
}

\author{
Theresa Squatrito
}

\begin{abstract}
Little attention has been given to understanding how international courts feature in legitimacy assessments. How should the performance of international courts be evaluated in terms of their effect on a democratic deficit in international lawmaking? This article takes an initial step toward understanding how international courts improve or weaken the presence of democratic values in international lawmaking. In particular, this article focuses on one aspect of international courts-access for transnational actors. This article argues that TNA access to international courts provides an institutional mechanism to advance participation and transparency in international lawmaking. Normative and empirical analysis are combined to illustrate the extent to which access applies to international courts. Based on the empirical findings, which show a marked increase in TNA access to international courts, I argue that the increased participation and transparency made available through TNA access have democratizing effects on international lawmaking.KEYWORDS: international courts, democracy, participation, transparency, transnational actors.
\end{abstract}

INTERNATIONAL LAW HAS DEVELOPED TO BE A PROMINENT COMPONENT OF GLOBAL governance. ${ }^{1}$ Some observers of this development argue that international lawmaking does not reflect the values of collective self-governance and suffers from democratic deficits. ${ }^{2}$ Such arguments often rest on the assumption that international lawmaking is dominated by states, with limited input from those affected by the rules states adopt. Yet international courts and tribunals (ICs) have grown in number and are widely recognized as important architects of international law. Against this backdrop, we can see that a significant gap in debates about the democratic deficits in international lawmaking arises from the lack of attention to international courts. How should we evaluate the performance of international courts in terms of their effect on the democratic credentials of international lawmaking?

This article takes an initial step toward understanding if and how ICs improve or weaken the presence of democratic values in international lawmaking. In particular, I home in on one feature of the institutional design of ICs and ask what potential role it plays in democratizing international lawmaking. The design feature of interest in this article is access for transnational actors (TNAs). Following recent literature, I conceive of TNAs as "the broad range of private actors that organize and operate across state borders, including nongovernmental orga- 
nizations (NGOs), advocacy networks, social movements, party associations, philanthropic foundations, and transnational corporations," among others. ${ }^{3}$ As an initial probe into the democratizing effects of international courts for international lawmaking, I focus on access for two reasons. First, existing literature highlights the relevance of TNA access to the democratic quality of global governance. ${ }^{4} \mathrm{Sec}-$ ond, access is a feature of ICs that, as I show, applies to most international courts. This focus enables a discussion of the democratizing effects of ICs in general, whereas other aspects of international courts require a case-by-case approach.

By examining one feature of ICs' institutional design, this article is a plausibility probe into whether the institutional design of ICs may shape and inform how ICs render the making of international law more democratic. Even though judicial practices and outputs are relevant to this question, for the purposes of this article I set them aside. My intention is not to exclude their relevance, but to begin a conversation by starting with institutional design.

I argue that TNA access to ICs provides an institutional mechanism that can enhance participation and transparency in international lawmaking. The greater the opportunities are for TNAs to access international courts, the better potential they have to make international lawmaking more inclusive and transparent. This argument combines normative and empirical analyses. Empirically, in the article I map TNA access to ICs since 1945, showing an expansion of access. My argument relies on a method of first identifying participation and transparency as values commonly featured by theories of democracy and then assessing if and how these values might be advanced by TNA access to ICs. Overall, I offer a normative contribution by highlighting how access to international courts has the potential to render international lawmaking more democratic while also making an empirical contribution by mapping access.

I present this argument in four parts. First, I explain why we need to include ICs when considering the democratic quality of international lawmaking, arguing that international courts play a role. Next, I map TNA access, illustrating that indeed access is a common feature of ICs today. Then, I identify participation and transparency as democratic values commonly featured in theories of democracy. I consider how TNA access can potentially improve the presence of these values in ICs and their role in lawmaking. I also argue that access is most relevant for its ability to act as institutional mechanisms of participation and transparency in international lawmaking. Finally, I conclude with a discussion of the implications of this argument for assessing democratic deficits in international lawmaking.

\section{International Courts and Lawmaking}

It is widely accepted today that international courts are no longer inconsequential institutions. ${ }^{5}$ They play important roles in global governance, including lawmaking. ${ }^{6}$ While there is contention as to whether ICs should make law, "theoretical assertions that deny law-making power to international judicial bodies ignore the 
reality that ... international courts ... do play a major law-making role." ${ }^{.7}$ In what ways do ICs contribute to international lawmaking? There is certain inevitability to judge-made law. ${ }^{8}$ As with any law, or system of rules, international law comprises abstract rules; it provides general prescriptions that cannot anticipate all possible circumstances to which they will apply. When asked to settle a dispute, ICs interpret the general rules and apply them to concrete cases. When doing so, they contribute to international lawmaking through two modes - by clarifying the meaning and scope of rules and by developing the law. First, ICs make law when they interpret and apply the law. This is because interpretation and application require a court to specify the meaning and scope of a legal rule, given a specific scenario. In other words, they fill gaps in the law in ways that stabilize normative expectations and give the law more predictability.

The second mode through which ICs make law is through progressive development of the law. Unlike the process of clarifying legal rules, which gives the law more predictability, ICs can significantly change a rule in a way that fundamentally alters its interpretation and application. Progressive development occurs when a decision advances the law's ability to address the changing conditions of international interactions. For example, the International Criminal Tribunal for Rwanda changed international criminal law by recognizing rape as an instrument of genocide. ${ }^{9}$

Developing the law occurs through three aspects of adjudication. First, ICs can at times be called on to interpret the scope of legal rules. In this capacity, an IC can significantly extend the scope of a rule. For example, the International Court of Justice (ICJ) and the International Criminal Tribunal for the former Yugoslavia have asserted that laws of war apply to internal conflicts. ${ }^{10} \mathrm{Or}$, the European Court of Justice (ECJ) has extended the scope of European Union (EU) law to include human rights. Second, ICs order rules. A central question frequently brought before courts pertains to which rules are superior. For example, do national laws trump international law? Similarly, ordering occurs when an IC determines whether a law is jus cogens or a customary law. By determining a law is jus cogens, such as torture, the court defines and develops the law such that the prohibition of torture is a supreme law. In other words, ICs define and develop the hierarchy of rules. Making these assessments, ICs change the ordering of principles in a way that significantly develops the law. Third, ICs determine how rules balance against one another to reconcile two conflicting rules. Balancing occurs both within a single legal regime and across legal regimes. An instance of the former is the European Court of Human Rights (ECtHR), which defines and develops the law by determining how to balance the rights of one individual against those of another. In the latter case, ICs can adjudicate instances when international trade law conflicts with international environmental law, for example, which the World Trade Organization (WTO) Appellate Body did in United States-Import Prohibition of Certain Shrimp and Shrimp Products. ICs can significantly modify how rules are balanced, contributing to the development of the law. 
Judicial decisions that either fill gaps or progressively develop the law often have lawmaking effects because judgments are treated as if they have precedential value. While judgments of ICs typically are binding only on the parties to a dispute, the reliance on previous judgments in legal argumentation gives judgments a lawmaking effect. Most ICs refer to previous judicial decisions, even though ICs vary in how elaborate their legal argumentation is and how extensively they draw on previous decisions. ${ }^{11}$ ICs do not necessarily refer to previous decisions as legally binding authority, but referring to and taking guidance from them is different from being bound by precedent. ${ }^{12}$ ICs use previous legal developments and perspectives on the law to develop a legal argument. Previous judicial rulings enhance the persuasiveness of an argument because they provide analogies, help to illustrate distinctions and patterns in meaning, and endorse certain perspectives or interpretations, even where precedent is not formally binding. ICs refer to their own previous decisions as well as to the decisions of other ICs. ${ }^{13}$ Thus, through legal argumentation, judgments of ICs have precedential effects, contributing to judicial lawmaking.

\section{TNA Access to International Courts}

Following previous research on TNA access, I conceive of TNA access as a dimension of the institutional design of international courts, which consists of the mechanisms whereby TNAs may take part in the judicial processes. ${ }^{14}$ Access to international institutions in general has been shown to offer some promises for democratizing global governance. ${ }^{15}$ Similarly, access for transnational actors to ICs might render international lawmaking more democratic. In this section I identify four types of access to international courts, defined as permanent international judicial bodies that meet the following criteria: (1) decide the question(s) brought before them on the basis of international law; (2) follow predetermined rules of procedure; (3) issue legally binding outcomes; (4) are composed of independent members; and (5) require that at least one party to a dispute is a state or an international organization. ${ }^{16}$

There are four types of TNA access: direct access, indirect access, thirdparty access, and public observer access. Direct access is governed by rules that grant TNAs privileges to directly file a petition to a court to have a complaint heard. Direct access enables individuals and groups, other than states or intergovernmental organs, the opportunity to litigate through an IC. Direct access is an important feature of more recently established ICs. ${ }^{17}$ Examples of ICs that grant direct access include the ECtHR and the Andean Tribunal of Justice. However, not all ICs feature direct access, including some recently established courts such as the Permanent Review Tribunal of Mercosur. Direct access allows TNAs to file petitions, but it does not guarantee that their case will be heard on the merits. Rather, petitions are first assessed for admissibility. 
The second type of access is indirect access. Indirect access is governed by rules that grant TNAs privileges to become a litigating party indirectly after another public authority brings their dispute to a court. One procedure that leads to indirect access is a referral by a national court. This is commonly found in regional trade courts and is exemplified by the ECJ's preliminary ruling procedure. Another indirect pathway is through an international commission, in combination with the acceptance of the court's jurisdiction by the relevant member state. Such a procedure exists in the Inter-American Court of Human Rights (IACtHR) and the African Court of Human and Peoples' Rights (ACtHPR). Also, there is the possibility that individual states recognize the right of individuals to directly petition a court. I treat these as indirect access because they require state acceptance separate from ratification of the contentious jurisdiction of the court. This applies to the ECtHR prior to 1998 and the ACtHPR.

Third, access to ICs transpires via rules that allow TNAs to participate in proceedings as a third party. ${ }^{18}$ Third parties can either be interveners or amicus curiae. While the privileges of an intervener are different from amicus, they are similar in that they offer a nonlitigant the opportunity to voice their interests and present information to the court. Many ICs provide third-party access, including the IACtHR, the ECJ, and the International Criminal Court.

The fourth type of access is public observer access, which is regulated by provisions that detail whether ICs' oral proceedings are held in public. Public hearings allow TNAs to observe the oral proceedings of ICs. While seemingly insignificant, some ICs maintain closed proceedings, preventing all nonlitigants from observing proceedings. Many ICs grant public observer access, but close proceedings to observers under limited exceptions. For example, Article 46 of the ICJ Statute requires that hearings are public "unless the Court shall decide otherwise, or unless the parties demand that the public be not admitted."19

These types of access are intended to be "ideal types" for analytical purposes. In practice, however, access arrangements vary, as additional rules determine the details of access for each court. Nevertheless, the ideal types are informed by access that currently exists in ICs. Also, these types of access include only those that are officially recognized by court treaties or rules of procedure. Informal access, such as lobbying efforts, is excluded from my discussion because they are not dimensions of institutional design. However, informal access may have consequences for democratic deficits in international lawmaking.

How accessible are international courts? Which types of access do ICs feature? To answer these questions, I map TNA access to ICs over time based on an original dataset on the design of twenty-four international courts. The ICs included in this dataset comprise the full universe of permanent ICs that were operational at any point from 1945 until the end of 2014 (see the Appendix for a list). ${ }^{20}$ Excluded are quasi-judicial bodies such as the UN human rights committees, tribunals with ad hoc appointments such as investor-state arbitration tribunals, hybrid criminal courts such as the Special Court for Sierra Leone, and 
ICs that were "nipped in the bud." 21 This selection of ICs matches other prominent comparative research on international courts. ${ }^{22}$ TNA access is coded based on the rules provided in treaties and protocols establishing international courts and in their rules of procedures as well as some case law that established new access measures (which applied in only a few instances). The data reflect changes in access during the lifetime of a court.

Figure 1 illustrates the development of access from 1945 to 2014. The figure shows that access grows as the number of ICs increase. ${ }^{23}$ This suggests that the increase in access is largely due to the creation of new ICs and that newly founded ICs have access at their origin. Only six ICs experienced changes in access after establishment (see the Appendix). As shown, the most common form of access is public observer access. In 2014, twenty ICs operated with the general rule that oral proceedings are public. Exceptions to this include the WTO Appellate Body, the Benelux Court of Justice, and the Mercosur Permanent Tribunal. ${ }^{24}$ The least common form of access is direct access. In 2014, fifteen ICs provided direct access. Direct access is usually provided by regional trade courts, but the ECtHR also features this form of access. Also, these patterns are consistent over time. Direct access has consistently been the least common form of access while public observer access has been the most common.

Figure 1 Development of Access from 1945 to 2014



Note: ICs, international courts and tribunals. 
Table 1 illustrates the overall accessibility of ICs by cross-sections of time. In 2010, the majority of courts featured either three or four types of TNA access. Also in 2010, it was most common for ICs to feature all four types of access while no ICs were completely closed. This is in contrast to 1995 , when access was less common. More than one-third of all ICs in 1995 either had no access or only one type, and only two ICs featured all types of access. So, the proportion of ICs that offer no access or only one type of access has declined over the past twenty years, and the proportion with three or more types has increased. As already mentioned, access rules have changed in a few ICs after their establishment. For example, third-party access was introduced in the WTO Appellate Body in 2000 and the Economic Community of West African States (ECOWAS) Court of Justice was adapted in 2005 to include direct and indirect access.

Table 1 Accessibility of ICs (by year)

\begin{tabular}{lccc}
\hline \multicolumn{3}{c}{ Number of ICs } \\
Accessibility & 1995 & 2000 & 2010 \\
\hline No access & $1(7.7 \%)$ & 0 & 0 \\
One type of access & $3(28.1 \%)$ & $4(23.5 \%)$ & $5(20.8 \%)$ \\
Two types of access & $2(15.4 \%)$ & $3(17.7 \%)$ & $4(16.7 \%)$ \\
Three types of access & $5(38.5 \%)$ & $5(29.4 \%)$ & $6(25.0 \%)$ \\
All types of access & $2(15.4 \%)$ & $5(29.4 \%)$ & $9(37.5 \%)$ \\
$N$ & 13 & 17 & 24 \\
\end{tabular}

Note: ICs, international courts and tribunals.

\section{Access to International Courts: Democratizing International Lawmaking}

The data reveal that TNA access has become a commonplace feature of ICs. How can we evaluate the democratizing benefits of access to ICs? I follow a method adopted by recent research that merges normative theory with empirical research, ${ }^{25}$ which first identifies values that are common to various theories and conceptions of democracy, and then assesses if and how these values are preserved in the empirical context. It should be noted that some theorists reject this approach, arguing that adding democratic values is not sufficient for democracy. ${ }^{26}$ I, however, do not claim that by enhancing the presence of certain values in international lawmaking it becomes democratic, but only that the presence of these values has the potential to render international lawmaking more democratic. Rather than highlighting a single model of democratic governance in this analysis, my argument builds on identifying values that are widely acknowledged as crucial to democratic governance and then asks if and how TNA access to ICs might better secure these values in international lawmaking. 
Participation and transparency are widely recognized as necessary (but not sufficient) values for democratic governance. Three core models of democracyparticipatory, representative, and deliberative democracy — highlight participation and transparency among the key criteria of democratic governance, albeit to varying degrees. Moreover, these two values can be identified in theories of democracy for the nation-state as well as for global governance.

Participation is viewed as an essential democratic value by different strands of democratic theory. ${ }^{27}$ Most perspectives on democracy in global governance have suggested that participation and participatory mechanisms are crucial to global democratization. ${ }^{28}$ Global deliberative democracy, global stakeholder democracy, and global cosmopolitanism - while varying in how they ultimately view the ideal global democracy - emphasize participation as essential to alleviating democratic deficits in global governance. Terry Macdonald, presenting the global stakeholder democracy, argues that "individuals should be entitled to participate in any decision-making that impacts in problematic ways upon their autonomous capacities." ${ }^{29}$ David Held, who presents ideas related to global cosmopolitanism, also emphasizes participation, arguing that democratic order hinges on whether "citizens were able to enjoy a bundle of rights which allowed them to command democratic participation." 30 Likewise, adherents of global deliberative democracy also see participation as central to democratic authority. ${ }^{31}$ In these various strands, participatory mechanisms are essential to making decision making more inclusive of and responsive to affected people, even though they cannot be equated to electoral participation.

Transparency is also generally viewed as an essential democratic value, and one that has potential to democratize global governance. ${ }^{32}$ Transparency is considered a crucial value for global democratization for several reasons. First, transparency is a cornerstone of participation. It plays an informational role that enables participation. Information asymmetries exist between the governing elites and the public. Simply put, the lack of information held by the public creates a de facto barrier to meaningful participation in global governance. Transparency mediates information asymmetries, transferring information available to elites to the public. With a more balanced distribution of information, the public is more readily equipped to participate. Second, transparency is a democratic value because of the ways in which it generates a public sphere of contestation. Transparency encourages public debate, and opportunities for civil society to participate at the international level can act as a "transmission belt" bringing international decision making to the wider public. ${ }^{33}$

Third, transparency enables those affected by transnational and national authority to scrutinize the exercise of authority. It is a necessary (albeit insufficient) condition for accountability. ${ }^{34}$ It is not enough for global governance to be transparent to states only. For transparency to act as a tool of accountability, it must be directed to those who hold ICs to account and may contest the terms of accountability. ${ }^{35}$ While states can be accountability holders, they are not 
the only ones. Transparency rather must provide civil society with information necessary for public scrutiny. The revisability of institutional practices and principles requires broad transparency, meaning that "information produced initially to enable institutionally designated accountability holders to assess officials' performance may be appropriated by agents external to the institutions, such as nongovernmental organizations (NGOs) and other transnational civil society, and used to support more fundamental criticism." ${ }^{36}$ Thus, transparency for external actors is essential for broad accountability, where the standards of accountability, and the accountability holders and their interests, can be contested. For these reasons, institutional mechanisms of transparency are widely considered to be crucial to democratizing global governance, even though transparency may come with some costs. ${ }^{37}$

Before proceeding, a few caveats must be mentioned. First, the argument does not assume that participation and transparency are sufficient remedies for democratic deficits. There may be other common values against which one could evaluate ICs in the democratizing of international lawmaking. For example, one might consider accountability or human rights. However, the link between these values and TNA access to ICs is less clear, and arguably better associated with other design features of ICs, such as jurisdiction, or even judicial outputs. For this reason, I set aside these other values. Second, as I explain further, additional factors condition the extent to which TNA access to ICs facilitates participation and transparency. Third, TNA access to ICs alone cannot fully democratize international lawmaking. Rather, I take the view that ICs are part of a broader set of institutions and actors involved in lawmaking. In this sense, I generally ascribe to a "system approach." ${ }^{38}$ My argument, thus, deals with only one aspect of the overall system. Nevertheless, on the whole TNA access to ICs has the potential to make international lawmaking more democratic than in its absence. Having identified important confines to my argument, I now turn to if and how TNA access to ICs might render international lawmaking more democratic.

\section{Participation and TNA Access to ICs}

TNA access to ICs can provide an institutional mechanism for participation in international lawmaking. Access rules entitle TNAs, or those affected by international law, to participate in international judicial processes that shape the content of international law. While a full range of factors (e.g., epistemic and monetary resources) may determine whether TNAs actually participate, TNA access is the institutional precondition to participation. In other words, access provides the possibility of participation in lawmaking by ICs, and the absence of access provisions prevents it.

The entitlements provided by TNA access mechanisms should be viewed as more than mere token privileges to participate. Rather, access to ICs can provide democratizing benefits because it enables those affected to influence lawmaking. TNA access to ICs can foster participation that has an impact of judicial 
lawmaking in two ways. First, access to ICs enables TNA actors to influence an IC's policy agenda, or the issues that are adjudicated. Specifically, direct and indirect access as litigants empower TNAs to influence what cases an IC hears because courts, unlike other political institutions, cannot pick the policy issues they consider. Rather, courts depend on cases to come to them, and their agendas are constructed primarily by what cases they receive. Thus, when TNAs are entitled to either directly or indirectly petition a court, they play a large role in determining what law and policy issues are on the court's docket.

Indeed, individual and societal groups' petitions to ICs have transformed the agendas of ICs in several instances. For example, TNA access was instrumental in leading the East African Court of Justice (EACJ) to address unexpected policy issues. Despite a lack of explicit authority to do so, the EACJ was called on to address issues of human rights and environmental protection because of petitions brought to the court by TNAs. ${ }^{39}$ Similarly, TNA access to the ECtHR contributed largely to questions of freedom of assembly and association. ${ }^{40}$

Indirect access through referral procedures also enables TNAs to participate in ways that shape ICs' agendas. For example, it was through the petition process at the Inter-American Human Rights system that territorial rights of indigenous peoples were placed on the agenda, even though they previously were not articulated in the Inter-American Human Rights Convention. ${ }^{41}$ Referrals to the ECJ led the court to adjudicate over women's rights and consequentially make gender equality a policy domain of the EU and the Court. ${ }^{42}$

These examples illustrate how provisions for direct and indirect access can translate into opportunities for TNAs to play a crucial role in determining what issues lie on the policy agenda of an IC. Access for TNAs contributes to an IC's agenda in ways that states could not, or would not. Nonstate litigants have incentives to bring claims against noncompliant states, whereas states have disincentives to do so. Concerns for retaliation and reputation can prevent states from filing claims against other states. Citizens, however, have incentives to do so, especially when social change is blocked through other pathways. ${ }^{43}$ Thus, direct and indirect access to ICs enables citizens to influence what issues are decided by ICs.

Second, access to ICs enables TNAs to participate in ways that ensure that deliberation and decision making are informed by a range of societal views and interests. In other words, TNA access can improve the "discursive quality" of judicial deliberation and lawmaking. ${ }^{44}$ Direct, indirect, and third-party access, in particular, are avenues through which TNAs' perspectives enter into international judicial lawmaking. While these forms of access technically grant TNA actors opportunity to present both factual information and legal arguments, as opposed to raw opinion, they nevertheless can be a means by which a court obtains information about the perspectives of those affected or interested in any given dispute. These forms of access introduce societal perspectives or discourses that would not otherwise enter into judicial lawmaking. States do not have an obligation to ensure that public interest or various societal perspectives are fairly represented 
in states' argumentation before an IC, nor do they have incentives to do so. Additionally, courts are not representative institutions because of their requirements of independence and impartiality. ${ }^{45}$ So they are not designed to incorporate diverse perspectives and interests through the individuals who sit on the bench. Thus, TNA access is crucial to broadening the scope of perspectives and interests that enter into international judicial deliberation.

Direct and indirect access ensures that at least one societal perspective- that of the nonstate litigant - is taken into account when deliberating and deciding a dispute. More important, however, is whether a broader set of perspectives or discourses may participate in the process. For this reason, third-party access can play an especially vital role in participation. For example, Sarah Williams and Hannah Woolaver found that "amicus can be very useful in ensuring that the perspective of these groups [victims and groups within society] is heard" during international criminal court proceedings. ${ }^{46}$ Without such opportunities to participate, the discourses present in judicial deliberation are guaranteed to be only that of the complainant and the respondent.

Some may argue that access to ICs does not ensure equal participation or that the access provided to international courts does not guarantee that those who participate have strong democratic credentials. The TNAs that participate before ICs are likely to be biased stakeholders and not representative voices. ${ }^{47}$ This criticism of TNA access claims that "those with the means and motive to make their voices heard, including NGOs and corporations, may not have spotless democratic credentials. Further, those who speak the most or the loudest may not represent the majority of the world." 48 Williams and Woolaver respond to similar criticisms when assessing amicus curiae before international criminal courts, and argue that most often the bias of an amicus is obvious and judges make independent assessments as to the value of its contribution. They find that "the risk of courts becoming battlegrounds for interest groups has not been realized before international criminal courts to date." ${ }^{\prime 49}$ I similarly argue that the forms of access that are provided by ICs are not unrestrained. Judges have the discretion to determine inadmissible claims, to not grant leave for amicus submissions, and to ultimately reject information that appears to be biased or irrelevant. In addition, it is possible that the solution to the capture of ICs by special interests does not lie with the exclusion of societal participants, but rather with their inclusion more broadly. In line with James Madison's well-known argument in the Federalist Paper No. 10, interests are best balanced against one another and merit more inclusion, rather than less.

It is clear, however, that participation that is generated by TNA access to ICs is not without imperfections. This form of participation is not equivalent to electoral participation or participation associated with direct democracy. Those who can participate, either for formal reasons such as meeting the criteria of having standing in legal proceedings or informal requirements such as financial resources, are limited. The participation that is provided may more closely resem- 
ble unelected or informal representation. ${ }^{50}$ Yet even if we view TNA access to ICs as providing representation only by actors who make "representative claims," there still may be good reason to view it on balance as more democratic by allowing for inclusion or representation of more views than in its absence.

Despite shortcomings, TNA access to ICs gives those affected more voice in the making of international law, and thereby may push international lawmakers to be more responsive to those governed than in its absence. TNA access to ICs serves as an institutional mechanism of participation, albeit an imperfect one. It provides those affected with greater capacity to shape the policy agenda of ICs. Also, access allows TNAs to influence the discursive quality of judicial deliberation and lawmaking by enabling more perspectives and interests to enter into the judicial process. The various forms of access provide the potential for participation, and thus might reduce democratic deficits - albeit to different degrees. Access has the greatest potential to democratize international lawmaking when its several forms are offered at the same time.

\section{Transparency and TNA Access to ICS}

TNA access to ICs provides a transparency mechanism in international lawmaking. As the empirical data reveal, most ICs provide public observer access, meaning that they operate with the general rule that oral proceedings will occur in open court, with the exception that they can be closed on account of extenuating circumstances. Public observer access, at a minimum, ensures that oral proceedings of a court are open to interested TNAs. This type of access can enable greater participation by the public, either directly or indirectly. For example, an organization that observes the hearings may find that the issues at hand relate to their interests, and may then seek to participate through more channels to air their views. Through public proceedings, civil society gains valuable information concerning the issues and interests at stake in a legal dispute as well as a sense of the legal problems and arguments surrounding a conflict. Similarly, access to proceedings may simply lead individuals to discuss the issue at hand in public fora. The ability for one or two individuals or groups to observe proceedings can have an impact on how seemingly remote and insular legal processes connect to wider public audiences and become the focus of political discourse.

This is not to imply that justices should make their own internal deliberations public, and that all aspects of the written proceedings must be publicly accessible. It is possible to ensure greater transparency of ICs while still valuing confidentiality and the secrecy of deliberations. ${ }^{51}$ Some transparency after the fact may be able to harness some of the benefits of transparency when we speak of courts. ${ }^{52}$

Access increases transparency to a greater extent when we consider other forms of access, including direct, indirect, and third-party access. Direct access as well as some forms of third-party access furnish additional transparency. Access as a litigant comes with full privileges to written and oral proceedings. Similarly, indirect access requires transparency for effective and fair judicial process. 
Likewise, some forms of third-party access would also entail having written proceedings being made readily available. These forms of access translate into transparency for those directly involved, and can contribute to broader transparency when involved TNAs relate information to the wider public. For example, the World Wildlife Fund (WWF) has acted as an amicus before WTO dispute panels. As a consequence, the WWF has published information on disputes to its members and on the Internet. Through this process, the issue then is transferred into the public sphere. As Armin von Bogdandy and Ingo Venzke argue, amicus submissions "might be able to trigger processes of scandalisation that contribute to discussions and mobilize the general public." ${ }^{53}$ While access may enable transparency and a subsequent heightening of public discourse around international courts, there may be a subsequent feedback effect where the IC is sensitized to the public discourse on the topic. As Robyn Eckersley explains, amicus submissions contribute to a public sphere around the WTO, "sensitizing the trade regime to the wider concerns of transnational civil society and thereby narrow the external accountability gap." 54

The transparency that access offers is far from perfect. Indeed, judicial deliberation does not transpire in an open forum, creating limits to what access can do for transparency. Nevertheless, access enhances the possibility of transparency in a way that is better than in its absence. Indeed, the temporal patterns illustrate that in some international courts, hearings are closed to the public. Moreover, TNA access is not the only means of ensuring transparency to international lawmaking by ICs. For example, rules may require ICs to make their judgments public.

To review, access to international courts may secure democratizing benefits to international lawmaking by fostering greater transparency. Specifically, transparency has the potential to boost participation and accountability, and create a public sphere around international adjudication and lawmaking. The various forms of access offer promise for transparency. The greatest promise for more transparency, similar to participation, would arise from a combination of different types of access. ICs that are designed to grant especially third-party access and public observer access would seem to have the best potential for increasing transparency and, thus, democratizing effects.

\section{Conclusion}

In this article, I aimed to bring international courts into the conversation on the democratic quality of international lawmaking. I argued that ICs are lawmaking institutions and should be given greater consideration when speaking of international lawmaking. Specifically, I proposed that international courts in their lawmaking role have significance for assessments of democratic deficits. My intent was to consider one particular feature of international courts that may render international lawmaking more democratic: this focus on TNA access to ICs corresponds to a body of literature that highlights the democratizing effects of 
TNA access. Mapping access to international courts, I showed that TNA access to ICs has expanded since 1945. I argued that if and how international courts grant access to TNAs can enhance the democratic values involved in international lawmaking through international courts. In particular, TNA access provides institutional mechanisms for participation and transparency — two widely recognized democratic values - in international lawmaking.

The democratizing effects generated by TNA access to ICs, however, are conditioned by various factors. I explained how the various types of access have different impacts on participation and transparency, and that the more access TNAs have to ICs the greater the potential impact. Two other considerations are likely to condition the potential democratizing effects of TNA access to ICs. First, there is significant variation among ICs in terms of their jurisdiction as well as their influence over international law. Second, not all TNAs are the same; NGOs, think tanks, and individuals, for example, differ in their material and epistemic resources and will therefore use access to different degrees. All of these factors condition the extent to which TNA access has democratizing effects on lawmaking through ICs. Nevertheless, on the whole, TNA access to ICs has the potential to make international lawmaking more democratic than in its absence-albeit to varying degrees depending on the types of access featured, the nature of an IC's jurisdiction, and who has access. Taking the perspective that, on the one hand, ICs are part of a broad system of lawmaking and, on the other hand, global democratization is a process that has only begun, TNA access to ICs moves us forward in this process. ${ }^{55}$

This article has implications for three debates. First, when considering the democratic quality of international lawmaking, ICs are relevant. International courts are de facto part of the making of international law, despite whether one believes they should be and despite the hesitance of states to admit that they have such a role. For this reason, ICs as lawmakers merit normative consideration. While I have focused on the democratizing effects of access for international lawmaking, other design features of international courts may either dampen or intensify democratic deficits. Second, I suggest that international lawmaking today takes on dynamics that differ from our traditional assumptions. When considering democratic deficits in international lawmaking, other dynamics are relevant yet unexplored. For example, treaty making today involves a wide range of transnational actors. ${ }^{56}$ If, how, and when the broader dynamics in international lawmaking affects global democratization begs consideration. I suggest that we look at how features of lawmaking processes dampen or intensify democratic deficits. Third, the literature on the democratic deficits in global governance has largely neglected international courts. ICs, however, deserve more attention in the debates concerning democracy in international lawmaking and global governance. The ways in which ICs can dampen and exacerbate democratic deficits are potentially plentiful, but little understood. This article, I hope, is a start to a broader discussion on ICs in global democratization. 


\section{Appendix}

\begin{tabular}{|c|c|c|}
\hline International Court & $\begin{array}{l}\text { Year in } \\
\text { Operation }\end{array}$ & Changes in Access \\
\hline $\begin{array}{l}\text { African Court of Human and Peoples' Rights } \\
\text { (ACtHPR) }\end{array}$ & 2006 & None \\
\hline Andean Tribunal of Justice (ATJ) & 1984 & $\begin{array}{l}\text { Yes (third-party access } \\
\text { added in 2001) }\end{array}$ \\
\hline Benelux Court of Justice (BCJ) & 1974 & None \\
\hline Central American Court of Justice (CACJ) & 1992 & None \\
\hline Caribbean Court of Justice (CCJ) & 2005 & None \\
\hline $\begin{array}{l}\text { Central African Economic and Monetary Commu- } \\
\text { nity Court of Justice (CEMAC CJ) }\end{array}$ & 2000 & None \\
\hline Court of Justice of the European Union (CJEU) & 1952 & $\begin{array}{l}\text { Yes (direct, third-party, and } \\
\text { public access added in 1957) }\end{array}$ \\
\hline $\begin{array}{l}\text { Common Market for Eastern and Southern Africa } \\
\text { Court of Justice (COMESA CJ) }\end{array}$ & 1998 & None \\
\hline East African Court of Justice (EACJ) & 2001 & None \\
\hline $\begin{array}{l}\text { Economic Court of the Commonwealth of Indepen- } \\
\text { dent States (ECCIS) }\end{array}$ & 1993 & None \\
\hline $\begin{array}{l}\text { Economic Community of West African States Court } \\
\text { of Justice (ECOWAS CJ) }\end{array}$ & 2002 & $\begin{array}{l}\text { Yes (direct and indirect party } \\
\text { access added in 2005) }\end{array}$ \\
\hline European Court of Human Rights (ECtHR) & 1959 & $\begin{array}{l}\text { Yes (third-party access } \\
\text { added in 1981, direct access } \\
\text { added in 1998, indirect } \\
\text { access removed in 1998) }\end{array}$ \\
\hline $\begin{array}{l}\text { European Free Trade Agreement Court of Justice } \\
\text { (EFTA CJ) }\end{array}$ & 1994 & None \\
\hline Inter-American Court of Human Rights (IACtHR) & 1979 & $\begin{array}{l}\text { Yes (third-party access } \\
\text { added in 1982) }\end{array}$ \\
\hline International Criminal Court (ICC) & 2002 & None \\
\hline International Court of Justice (ICJ) & 1947 & None \\
\hline International Criminal Tribunal of Rwanda (ICTR) & 1994 & None \\
\hline $\begin{array}{l}\text { International Criminal Tribunal of the Former } \\
\text { Yugoslavia (ICTY) }\end{array}$ & 1993 & None \\
\hline $\begin{array}{l}\text { International Tribunal for the Law of the Sea } \\
\text { (ITLOS) }\end{array}$ & 1996 & None \\
\hline $\begin{array}{l}\text { Mercosur Permanent Review Tribunal (Mercosur } \\
\text { PRT) }\end{array}$ & 2002 & None \\
\hline $\begin{array}{l}\text { Organization for the Harmonization of Business Law } \\
\text { in Africa Common Court of Justice and Arbi- } \\
\text { tration (OHADA CCJA) }\end{array}$ & 1996 & None \\
\hline $\begin{array}{l}\text { Tribunal of the Southern African Development Com- } \\
\text { munity (SADCT) }\end{array}$ & $\begin{array}{l}2005- \\
2010\end{array}$ & None \\
\hline $\begin{array}{l}\text { Western African Economic and Monetary Union } \\
\text { Court of Justice (WAEMU CJ) }\end{array}$ & 1995 & None \\
\hline $\begin{array}{l}\text { World Trade Organization Appellate Body (WTO } \\
\qquad \text { AB) }\end{array}$ & 1994 & $\begin{array}{l}\text { Yes (third-party access } \\
\text { added in 1998) }\end{array}$ \\
\hline
\end{tabular}




\section{Notes}

Theresa Squatrito is a lecturer at the University of Liverpool. Previously, she was a postdoctoral research fellow at the PluriCourts Centre of Excellence at the University of Oslo.

This work was partly supported by the Research Council of Norway through its Centres of Excellence funding scheme, Project No. 223274. The author would like to thank the Research Council of Norway for its generous support.

1. Judith Goldstein, Miles Kahler, Robert O. Keohane, and Anne-Marie Slaughter, "Introduction: Legalization and World Politics," International Organization 54, no. 3 (2000): 385-399.

2. Robert E. Goodin and Steven R. Ratner, "Democratizing International Law," (2011) Global Policy 2, no. 3 (2011): 241-247. Other authors contest whether democracy applies to international institutions or whether there is a democratic deficit. See Andrew Moravcsik, "Is There a 'Democratic Deficit' in World Politics? A Framework for Analysis," (2004) Government and Opposition 39, no. 2: 336-363; Robert Dahl, "Can International Organizations Be Democratic? A Skeptic's View," in Ian Shapiro and Casiano Hacker-Cordón, eds., Democracy's Edges (Cambridge: Cambridge University Press, 1999), pp. 19-36.

3. Magdalena Bexell, Jonas Tallberg, and Anders Uhlin, "Democracy in Global Governance: The Promises and Pitfalls of Transnational Actors," Global Governance 16, no. 1 (2010): 81. See also Jonas Tallberg, Thomas Sommerer, Theresa Squatrito, and Christer Jönsson, The Opening Up of International Organization: Transnational Access in Global Governance (Cambridge: Cambridge University Press, 2013).

4. Tallberg et al., The Opening Up of International Organization; Jens Steffek, Claudia Kissling, and Patrizia Nanz, Civil Society Participation in European and Global Governance: A Cure for the Democratic Governance (New York: Palgrave Macmillan, 2008).

5. Yuval Shany, "No Longer a Weak Department of Power? Reflections on the Emergence of a New International Judiciary," European Journal of International Law 20, no. 1 (2009): 73-91.

6. Karen J.Alter, "The Multiple Roles of International Courts and Tribunals: Enforcement, Dispute Settlement, Constitutional and Administrative Review," in Jeffrey Dunoff and Mark Pollack, eds., Interdisciplinary Perspectives on International Law and International Relations (Cambridge: Cambridge University Press, 2013), pp. 345-370.

7. Alan E. Boyle and Christine Chinkin, The Making of International Law (Oxford: Oxford University Press, 2007), p. 268.

8. Martin Shapiro, Courts: A Comparative and Political Analysis (Chicago: University of Chicago Press, 1981); Tom Ginsburg, "Bounded Discretion in International Judicial Lawmaking," Virginia Journal of International Law 45, no. 3 (2005): 631673.

9. Kelly Dawn Askin, "Gender Crimes Jurisprudence in the ICTR," Journal of International Criminal Justice 3, no. 4 (2005): 1007-1018.

10. Eve La Haye, War Crimes in Internal Armed Conflicts (Cambridge: Cambridge University Press, 2008).

11. Joost Pauwelyn and Manfred Elsig, "The Politics of Treaty Interpretation: Variations and Explanations Across International Tribunals," in Jeffrey Dunoff and Mark 
Pollack, eds., Interdisciplinary Perspectives on International Law and International Relations (Cambridge: Cambridge University Press, 2014), p. 456.

12. Ibid.

13. Gilbert Guillaume, "The Use of Precedent by International Judges and Arbitrators," Journal of International Dispute Settlement 2, no. 1 (2011): 5-23; Erik Voeten, "Borrowing and Nonborrowing Among International Courts," Journal of Legal Studies 39, no. 2 (2010): 547-576.

14. Tallberg et al., The Opening Up of International Organization.

15. Bexell, Tallberg, and Uhlin, "Democracy in Global Governance"; Jens Steffek and Patrizia Nanz, "Emergent Patterns of Civil Society Participation in Global and European Governance," in Jens Steffek, Claudia Kissling, and Patrizia Nanz, eds., Civil Society Participation in European and Global Governance (Basingstoke: Palgrave Macmillan, 2008), pp. 1-29.

16. Cesare Romano, Karen Alter, and Yuval Shany, "Mapping International Adjudicative Bodies, the Issues, and Players," in Cesare Romano, Karen Alter, and Yuval Shany, eds., The Oxford Handbook of International Adjudication (Oxford: Oxford University Press, 2014), p. 6. For a complete list and the criteria for selection, see Karen Alter, The New Terrain of International Law: Courts, Politics, Rights (Princeton: Princeton University Press, 2014).

17. Karen Alter, "Private Litigants and the New International Courts," Comparative Political Studies 39, no. 1 (2006): 22-49.

18. In some instances, third party refers to access by a state or intergovernmental organ. For the purposes here, I do not include these in the analysis.

19. Statute of the International Court of Justice (adopted 26 June 1945, entered into force 24 October 1945) 3 Bevans 1179; 59 Stat. 1055; TS No. 993.

20. Permanence is defined by having judges who hold permanent positions, as opposed to ad hoc appointments; see Cesare Romano, "A Taxonomy of International Rule of Law Institutions," Journal of International Dispute Settlement 2, no. 1 (2011): 262.

21. Cesare Romano, "Trial and Error in International Judicialization," in Cesare Romano, Karen Alter, and Yuval Shany, eds., The Oxford Handbook of International Adjudication (Oxford: Oxford University Press, 2014), pp. 11-134.

22. Alter, The New Terrain of International Law.

23. The decrease from 2010 to 2011 reflects the suspension of the Tribunal of the Southern African Development Community (SADC). For literature on the growth in ICs, see Alter, "Private Litigants and the New International Courts"; Bernhard Zangl et al., "Between Law and Politics: Explaining International Dispute Settlement Behavior," European Journal of International Relations 18, no. 2 (2012): 369-401; Goldstein et al., "Introduction"; Karen Alter, "The Global Spread of European Style International Courts," West European Politics 35, no. 1 (2012): 134-154.

24. Since 2005, hearings at the World Trade Organization (WTO) are open to the public on the consent of all parties. See Lothar Ehring, "Public Access to Dispute Settlement Hearings in the World Trade Organization," Journal of International Economic Law 11, no. 4 (2008): 1021-1034.

25. For example, see Bexell, Tallberg, and Uhlin, "Democracy in Global Governance"; Jonathan W. Kuyper, "Global Democratization and International Regime Complexity," 
European Journal of International Relations 20, no. 3 (2014): 620-646; Klaus Dingwerth, "The Democratic Legitimacy of Public-private Rule Making: What Can We Learn from the World Commission on Dams?" Global Governance 11, no. 1 (2005): 65-83.

26. Eva Erman, "Why Adding Democratic Values Is Not Enough for Global Governance," in Eva Erman and Anders Uhlin, eds., Legitimacy Beyond the State? Re-examining the Democratic Credentials of Transnational Actors (Basingstoke: Palgrave Macmillan, 2010), pp. 173-193.

27. Carol Pateman, Participation and Democratic Theory (Cambridge: Cambridge University Press, 1970); Robert A. Dahl, A Preface to Democratic Theory (Chicago: Chicago University Press, 1956); Jürgen Habermas, Between Facts and Norms: Contributions to a Discourse Theory of Law and Democracy (Cambridge: MIT Press, 1996).

28. Bexell, Tallberg, and Uhlin, "Democracy in Global Governance"; Kuyper, "Global Democratization and International Regime Complexity"; Klaus Dingwerth, The New Transnationalism: Transnational Governance and Democratic Legitimacy (Basingstoke: Palgrave Macmillan, 2007).

29. Terry Macdonald, Global Stakeholder Democracy: Power and Representation Beyond Liberal States (New York: Oxford University Press, 2008), p. 41.

30. David Held, Democracy and the Global Order: From the Modern State to Cosmopolitan Governance (Cambridge: Polity Press, 1995), p. 190.

31. John S. Dryzek, Deliberative Democracy and Beyond: Liberals, Critics, Contestations (Oxford: Oxford University Press, 2000).

32. Jan Aart Scholte, Building Global Democracy: Civil Society and Accountable Global Governance (Cambridge: Cambridge University Press, 2011); Steffek, Kissling, and Nanz, Civil Society Participation in European and Global Governance; Macdonald, Global Stakeholder Democracy.

33. Steffek and Nanz, "Emergent Patterns of Civil Society Participation in Global and European Governance," pp. 8-11.

34. Buchanan and Keohane, "The Legitimacy of Global Governance Institutions," Ethics \& International Affairs 20, no. 4 (2006): 405-437; Scholte, Building Global Democracy; Thomas N. Hale, "Transparency, Accountability, and Global Governance," Global Governance 14, no. 1 (2008): 73-94.

35. Buchanan and Keohane, "The Legitimacy of Global Governance Institutions," p. 436 .

36. Ibid., p. 428 (emphasis in original).

37. Daniel Naurin, "Transparency and Legitimacy," in Lynn Dobson and Andreas Føllesdal, eds., Political Theory and the European Constitution (London: Palgrave, 2004), pp. 139-150; Jon Elster, "Deliberation and Constitution Making," in Jon Elster, ed., Deliberative Democracy (Cambridge: Cambridge University Press, 1998).

38. John Parkinson and Jane Mansbridge, eds., Deliberative Systems: Deliberative Democracy at the Large Scale (Cambridge: Cambridge University Press, 2012).

39. James Gathii, "Mission Creep or a Search for Relevance: The East African Court of Justice's Human Rights Strategy," Duke Journal of Comparative and International Law 24, no. 2 (2013): 249-296; James Gathii, "Saving the Serengeti: Africa's New International Judicial Environmentalism," Chicago Journal of International Law 16, no. 2 (2016): 386-438.

40. Anna-Karin Lindblom, Non-governmental Organisations in International Law (Cambridge: Cambridge University Press, 2005), p. 255. 
41. Inter-American Commission on Human Rights, "Indigenous and Tribal Peoples' Rights over Their Ancestral Lands and Natural Resources: Norms and Jurisprudence of the Inter-American Human Rights System" (Washington, DC: OAS, 2010), www.oas.org /en/iachr/indigenous/docs/pdf/ancestrallands.pdf.

42. Rachel A. Cichowski, "Women's Rights, the European Court and Supranational Constitutionalism," Law and Society Review 38, no. 3 (2004): 489-512.

43. Margaret E. Keck and Kathryn Sikkink, Activists Beyond Borders: Advocacy Networks in International Politics (Ithaca: Cornell University Press, 1998).

44. Dingwerth, The New Transnationalism, p. 47.

45. Armin Von Bogdandy, “The Democratic Legitimacy of International Courts: A Conceptual Framework," Theoretical Inquiries in Law 14, no. 2 (2013): 370.

46. Sarah Williams and Hannah Woolaver, "The Role of Amicus Curiae Before International Criminal Tribunals," International Criminal Law Review 6, no. (2006): 185.

47. Joel P. Trachtman and Philip M. Moremen, "Costs and Benefits of Private Participation in WTO Dispute Settlement: Whose Right Is It Anyway?" Harvard International Law Journal 44, no. 1 (2003): 221-250.

48. Nienke Grossman, "The Normative Legitimacy of International Courts," Temple Law Review 86, no. 1 (2013): 93.

49. Williams and Woolaver, "The Role of Amicus Curiae Before International Criminal Tribunals," p. 87.

50. Michael Saward, The Representative Claim (Oxford: Oxford University Press, 2010).

51. Armin von Bogdandy and Ingo Venzke, "On the Democratic Legitimation of International Judicial Lawmaking," German Law Journal 12, no. 5 (2011): 1363-1364.

52. Joseph S. Nye, "Globalization's Democratic Deficit: How to Make International Institutions More Accountable," Foreign Affairs 80, no. 4 (2001): 5.

53. Bogdandy and Venzke, "On the Democratic Legitimation of International Judicial Lawmaking," p. 1366.

54. Robyn Eckersley, "A Green Public Sphere in the WTO? The Amicus Curiae Interventions in the Transatlantic Biotech Dispute," European Journal of International Relations 13, no. 3 (2007): 331.

55. Robert E. Goodin, "Global Democracy: In the Beginning," International Theory 2, no. 2 (2010): 175-209.

56. Boyle and Chinkin, The Making of International Law. 